\title{
EDUCATIONAL TECHNOLOGY FOR ACTIVE CONNECTIONS IN BLENDED LEARNING ENVIRONMENTS
}

\author{
Philip Uys, Charles Sturt University, Australia
}

\section{Introduction}

This conference focuses on employing educational technology for connections. It assumes that these connections will be active, and not latent - otherwise these will be meaningless and ineffective. The emphasis is thus on creating effective learning environments. Such learning environments are not just online or digital, but can also be physical learning spaces in which educational technology can play a key role.

A key strategy to ensure that educational technology connections are indeed active is to employ educational technology within an active learning framework for both online and oncampus learning i.e. blended learning. Educational technology on its own does not lead to active learning - only when it is used within well-founded learning designs - of which constructive alignment is highlighted below. I am thus agreeing with Veletsianos and Moe (2017) that educational technology by itself is not "education's silver bullet" but should be located within "the essentials of teaching and learning: theory, pedagogy and emergent trends in the research." Such active learning will lead to learner engagement, leading to effective learning and learner success.

The vision for instance for educational technologies at Charles Sturt University is to "support educational practices focussed on student success by providing cutting edge, stable learning environments".

\section{Literature review}

This cursory literature review explores the concepts of learning spaces, learning environments, blended learning, constructive alignment, and active learning - all within the context of educational technology enabling active connections for effective learning.

\section{Learning spaces and learning environments}

Learning spaces in the context of higher education refer to physical, digital and cognitive learning environments (Oblinger, 2006). The terms learning spaces and learning environments are thus used interchangeably in this paper. Learning spaces are further not just the traditional classrooms but all "spaces" where formal and informal learning occurs - for instance in libraries (Bridgland \& Blanchard, 2001; Keating \& Gabb, 2005, Lonsdale, 2003), 
laboratories, workplaces, green spaces (Massey, 2004), and a variety of other locations - both offline and online.

\section{Blended learning}

The concept of blended learning acknowledges the above: learning, if not fully online, in many cases now occurs as a thoughtful (Stacey \& Gerbic, 2008) blend or convergence of face-to-face interactions and online learning activities (Garrison \& Vaughan, 2008; Graham, 2006). The challenge is thus to ensure effective blended learning environments - not merely in purely online or purely face-to-face environments.

\section{Constructive alignment}

Biggs (2003; p.27) similarly focuses the attention on the active involvement of the learner, and defines constructive alignment as "the 'constructive' aspect refers to what the learner does, which is to construct meaning through relevant learning activities. The 'alignment' aspect refers to what the teacher does, which is to set up a learning environment that supports the learning activities appropriate to achieving the desired learning outcomes". In consulting assignments of the writer in various settings, constructive alignment has been used to guide workshop participants to define learning activities based on learning outcomes and assessment, and only thereafter consider content delivery or content creation - the focus being on actions by the learner.

\section{Active learning}

It is proposed that active learning, which well aligns with the tenets of constructive alignment, leads to effective blended learning environments that is supported by educational technology.

\section{What is active learning?}

Active learning is "students doing things and thinking about what they are doing" (Bonwell \& Eison, 1991). It involves and engages learners in the learning processes which is opposed to a transmission approach (Freire, 1970) and provides greater agency to learners but also require thought and reflection about the learning taking place (Horton \& Freire, 1990). Michael (2006) describes active learning as "the process of keeping students mentally, and often physically, active in their learning through activities that involve them in gathering information, thinking, and problem solving".

\section{Why active learning?}

It is clear from the literature that learner engagement leads to learning and learner success (Kahu \& Nelson, 2018; Nelson, Readman, \& Stoodley, 2018). Kahu and Nelson (2018) depict it as follows in Figure 1. 


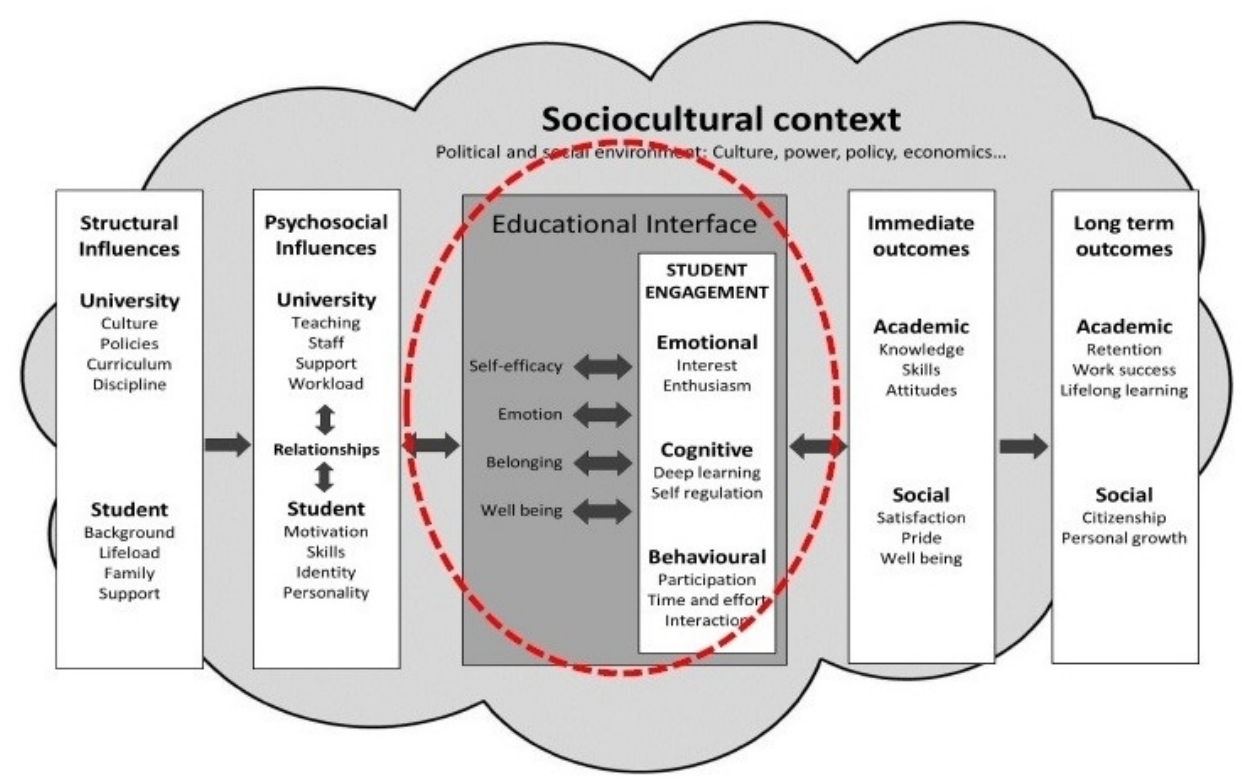

Figure 1. Refined conceptual framework of student engagement

Active learning, fully supported by educational technology, is a key strategy to ensure learning engagement, thus leading to effective learning and learner success. It can be depicted as follows in Figure 2.

Learner engagement is a key contributor to effective learning and learner success

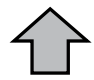

Active learning leads to learner engagement

Appropriate use of educational technologies within thought-through learning designs

Figure 2. Relationship between learner engagement, learner success, active learning and educational technologies

Michael (2006) furthermore reviewed the evidence from a large volume of literature and various fields (exceeding 100 sources) indicating that "active learning works" and is more effective than more passive approaches.

\section{Using educational technologies for active learning in blended learning environments}

In the online dimension of blended learning, a myriad of educational technologies is available to support active learning. Learning management systems (LMSs) in themselves provide a variety of technologies. Moodle, the largest open source LMS internationally, provides facilities for collaboration on online and mobile devices (groups, forums, wikis, glossaries); for interaction (games, forums, chat, messaging, online-conferencing); for communication 
(messaging, announcements, calendar); for assessment (assignments, quizzes, grading/marking, feedback, assignment submission); for managing resources (pages, book, bookmarking), and for learner management. The Moodle Plugin directory now has more than 1,500 listed plugins. In addition to LMSs there are further a vast array of (often free) external educational technologies and social media tools available to support active learning. These educational technologies connect the learner to the teacher, the learners to each other, and learners to learning activities and resources.

Many of these technologies are accessible by mobile devices that can be used offline, and further support other off-line use - thus supporting active learning in face-to-face environments. In face-to-face environments there are educational technologies available to conduct polls in classrooms, group-work through online participation in class, the use of smartboards, augmented reality, virtual reality, movable computer displays, flexible furniture, shared writing surfaces, and simulations like intelligent paramedic patient dummies. Using such educational technologies creates blended environments where face-to-face and online activities are integrated. The flipped classroom is similarly an approach that was designed for face-to-face learning (introduced as the Thayer Method in 1835) often using educational technologies such as web searches, online exercises, and reviewing online resources before class. At the University of Technology, Sydney (date unknown) "online pre-labs were introduced, requiring students to complete a series of questions based on material presented in lectures before coming to class." EDUCAUSE (2012; p.1) describes the flipped classroom as a "pedagogical model in which the typical lecture and homework elements of a course are reversed". This definition blurs in the online environment as it is not possible to easily define what is "before class" and what is "during class". Honeycutt and Glova (2014) posit thus that "at its core, the flip means shifting the focus from the instructor to the students" indicating that the flipped classroom in the blended learning environment, be it integrated, face-to-face or online, is about focussing on activities by the learners "to construct knowledge, connect with others, and engage in higher levels of critical thinking and analysis". Jenkins et al. (2017) acknowledges though the continued role of the teacher and the role of "content" in their "Flipped Learning Matrix model".

The writer proposes that physical learning spaces (for formal and informal learning) itself can be seen as educational technology potentially supporting, or inhibiting, active learning in blended learning environments. Its impact is so significant on learning that it has been described as the "third teacher" (Pigozzi et al., 2010). Examples of active learning enabled by physical spaces range from group work and mind mapping to project work. Figure 3 depicts a blended, collaborative arrangement at Charles Sturt University linking online and face-to-face technologies and encouraging active learning. 


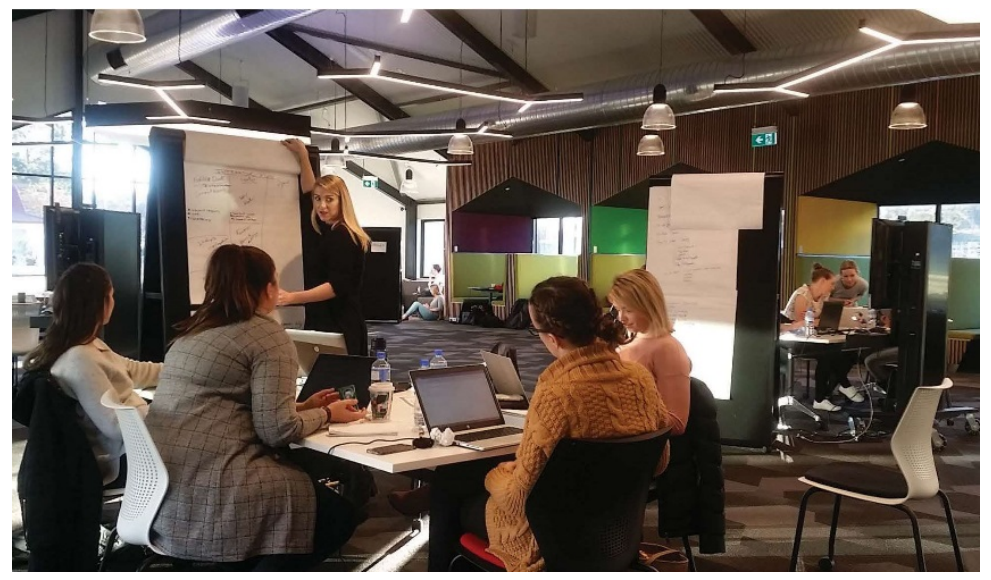

Figure 3.

At Case Western Reserve University an active learning project occurred in two rooms with blended technologies, "optimized for collaboration both within the classroom and through telecommunication with others off campus" and reported very positive outcomes (Juergensen et al., 2015). These rooms used "large displays that let students collaborate on projects and flexible furniture that can be easily reconfigured to suit various learning activities. The classes also featured bright colours and shared writing surfaces, including multiple white boards and writable walls". The project report included the following quotes from two students:

"I am so engaged that I didn't clock watch at all. Is there a clock in here? I didn't even notice that."

"Doing a class like this in just one format may get boring. Having so many different methodologies using these different technologies made it more interesting and informative. I need more going on than just PowerPoint. Using these different ways to learn is much more engaging."

At Charles Sturt University a 2019-initiative is the development of a learning spaces portal (following a successful pilot last year), to encourage active learning by displaying on mobile devices or online, the layout of each teaching room, technology and furniture available, and active learning strategies that can be used in the room. 


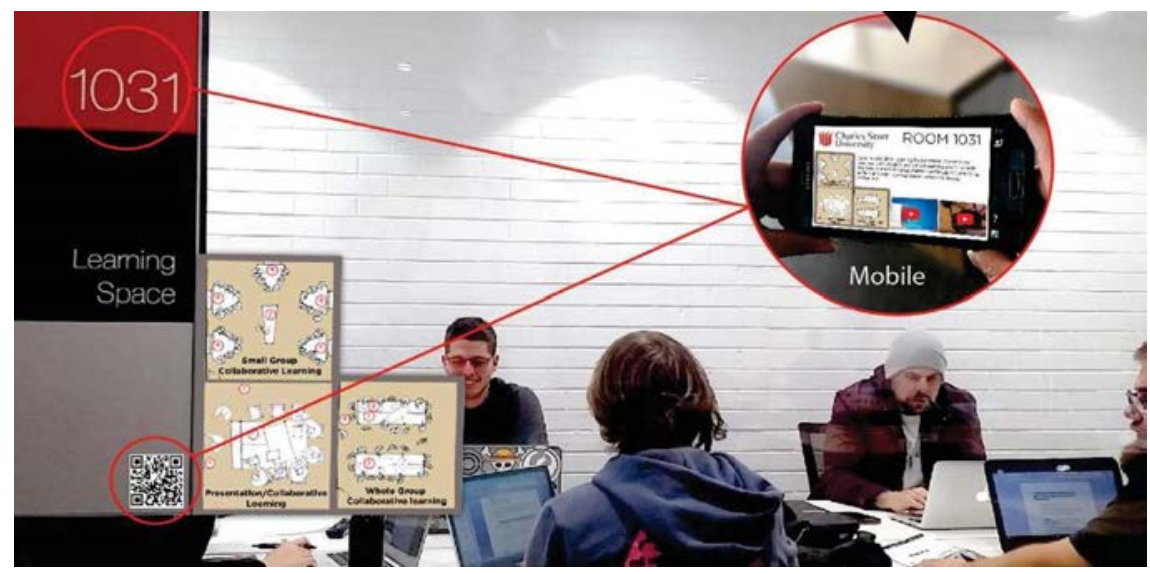

Figure 4. Learning spaces portal under development at Charles Sturt University: accessing information on a mobile device

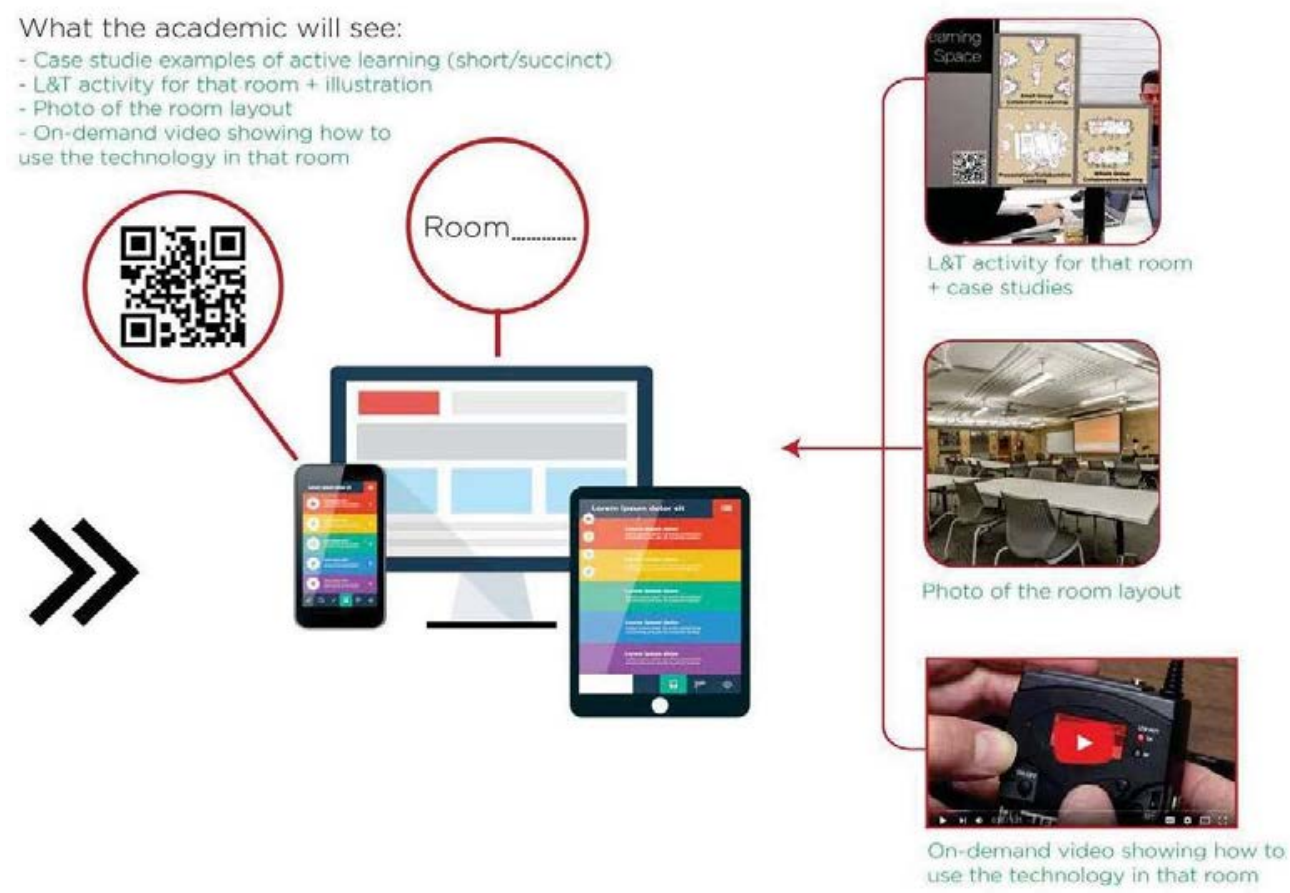

Figure 5. Earning spaces portal under development at Charles Sturt University: what the teacher sees

\section{Conclusion}

Educational technology can indeed be used to create active connections for blended learning by supporting and enabling active learning. Educational technology can thus play a key role in creating effective blended, online, face-to-face, digital or physical learning environments. The fundamental precondition is that educational technology is employed within an active learning framework, based on the tenets of constructive alignment, thus leading to student engagement and ultimately effective learning and learner success. 


\section{References}

ACODE (2018). Introduction to Learning Spaces. Retrieved from https://www.acode.edu.au/course/view.php?id=28\&section=1

Biggs, J. B. (2003). Teaching for quality learning at university ( $2^{\text {nd }}$ ed.). Buckingham: Open University Press/Society for Research into Higher Education.

Bonwell, C., \& Eison, J. (1991). Active learning: Creating excitement in the classroom (ASHEERIC Higher Education Report No. 1). Washington, DC: George Washington University.

Bridgland, A., \& Blanchard, P. (2001). Flexible delivery/flexible learning ... does it make a difference? Australian Academic \& Research Libraries, September, 177-191.

EDUCAUSE Learning Initiative (2012). 7 Things You Should Know About Flipped Classrooms. EDUCAUSE Learning Initiative (ELI).

Freire, P. (1970). Pedagogy of the Oppressed. New York: Herder and Herder.

Garrison, R., \& Vaughan, H. (2008). Blended learning in higher education: Framework, principles and guidelines. San Francisco: Jossey-Bass.

Graham, C. (2006). Blended learning systems. Definitions, current trends and future directions. In C. Bonk \& C. Graham (Eds.), The handbook of blended learning: Global perspectives, local designs. San Francisco: John Wiley and Sons.

Honeycutt, B., \& Glova, S. (2014, March 31). Can You Flip an Online Class? Faculty Focus. Faculty Focus [Blog post]. Retrieved from https://www.facultyfocus.com/articles/blendedflipped-learning/can-flip-online-class/

Horton, M., \&Freire, P. (1990). We Make the Road by Walking. Philadelphia, PA: Temple University Press.

Hua, P., Uys, P. M., \& Eeles, P. (2017). Adapting to new learning spaces: resistance and remedies. Paper presented at the CSU Digital Showcase. 2018 IUT Conference, Port Macquarie, Australia.

Jenkins, M., Bokosmaty, R., Brown, M., Browne, C., Gao, Q., Hanson, J., \& Kupatadze, K. (2017). Enhancing the design and analysis of flipped learning strategies. Teaching \& Learning Inquiry, 5(1). Retrieved from http://dx.doi.org/10.20343/teachlearninqu.5.1.6

Juergensen, J., Oestreich, T., Yuhnke, B., Kenney, M., Skapin, K., \& Shapiro, W. (2015, January 26). Active Learning at Case Western University. EDUCAUSE Review [Blog post]. Retrieved from https://er.educause.edu/articles/2015/1/active-learning-at-casewestern-university

Kahu, E. R., \& Nelson, K. (2018). Student engagement in the educational interface: understanding the mechanisms of student success. Higher Education Research \& Development, 37(1), 58-71. Retrieved from http://www.tandfonline.com/doi/full/10.1080/07294360.2017.1344197 
Keating, S., \& Gabb, R. (2005). Putting learning into the learning commons: A literature review. Postcompulsory Education Centre, Victoria University.

Lonsdale, M. (2003). Impact of School Libraries on Student Achievement. A review of the research. Melbourne: Australian Council for Educational Research.

Massey, S. (2004). The benefits of a Forest School experience for children in their early years. Forest school in Worcestershirelea, 10.

Michael, J. (2006). Where's the evidence that active learning works? Advances in Physiology Education, 30, 159-167.

Nelson, K., Readman, K., \& Stoodley, I. (2018). Shaping the $21^{\text {st }}$ century student experience at regional universities. Final report: 2018. Canberra: ACT. Retrieved from http://shapingtheregionalstudentexperience.com.au/wp-content/uploads/2018/06/SP144602_NelsonandReadman_Report_2018.pdf

Oblinger, D. (2006). Learning Spaces. EDUCAUSE Review.

Pigozzi, O. W., Peterson \& Mau, B. (2010). The Third Teacher. Retrieved from http://thethirdteacherplus.com/resources/

Stacey, E., \& Gerbic, P. (2008). Success factors for blended learning. Hello! Where are you in the landscape of educational technology? Proceedings of the ASCILITE Conference, Melbourne 2008, 964-968. Retrieved from http://www.ascilite.org/conferences/melbourne08/procs/stacey.pdf

University of Technology Sydney (n.d.). learning.futures in the classroom. Retrieved from https://www.uts.edu.au/research-and-teaching/learning-andteaching/learningfutures/learningfutures-classroom

Veletsianos, G., \& Moe, R. (2017, April 10). The Rise of Educational Technology as a Sociocultural and Ideological Phenomenon. EDUCAUSE Review [Blog post]. Retrieved from https://er.educause.edu/articles/2017/4/the-rise-of-educational-technology-as-asociocultural-and-ideologicalphenomenon?lipi=urn\%3Ali\%3Apage\%3Ad_flagship3_feed\%3BgTGfmuchTny2kpDc2Aj tlA\%3D\%3D 